No. 5(62), 2019, pp. 33-50

https://doi.org/10.12797/Politeja.16.2019.62.03

\author{
Ivan V. RADIKOW (D) \\ Saint Petersburg State University \\ ivirrad@gmail.com
}

\title{
TRUST IN THE PROCESS OF COOPERATION BETWEEN THE CITIZENS AND THE STATE IN CONTEMPORARY RUSSIA
}

ABSTRACT The author claims that contemporary cooperation between the state and a citizen in Russia is evolving from a state-centralist model to a kind of partnership. The degree and quality of the state's cooperation is determined by the hybrid nature of the Russian political system - a combination of elements of democratic institutions and autocratic methods of governance. Cooperation between the state and a citizen should be discussed in the context of attaining the opportunities for cooperation between the citizens and the state in order to achieve general aims, as a means of resolving problems. The author holds the opinion that cooperation can be not only an expression of solidarity, but also a testament to peaceful coexistence (not aimed at wrangling). What serves as an indicator of such cooperation between the state and a citizen is trust in the authorities. It should be said that in the conditions of unconsolidated democratic culture of cooperation between the state and the society, the attitude of the majority of citizens to the contemporary political authorities in Russia is, to a high degree, based on trust in Vladimir Putin. However, the noticeable decrease in the level of trust to certain institutions of authority is a result of the inaction, immorality, and corruption of certain groups of policymakers or representatives of the authorities. One of the major challenges of the authorities is how to increase social trust in political institutions.

Key words: Russia, society, state, lack of trust, cooperation, trust-level dynamics 


\section{INTRODUCTION}

In history, there have been at least three models of cooperation between state and citizen. The first model is state-centric: paternalistic (Confucius), etatistic or statocractic (Plato, Aristotle, Zoroaster), and it absolutized and sacralized the role of a state, demanded full subordination of the interests of an individual to its interests and recognized every interference of a state in all spheres of life of an individual and a society as legal. The paternalistic model assumed a state's "paternal" care of the citizen from their birth to their death. The second model - partnership - predicts the presence of an effective mechanism of reaching an agreement on goals and interests of a state and those of an individual. It rejects uncivilized methods of resolving disputes between them and is based on mutual (state's and citizen's) readiness to arrive at a compromise as well as to harmonize their interests. Such cooperation facilitates a high level of trust in the state's institution among citizens and permanent social order. The third model - anthropocentric - regards people as the main social value, and their development, security, and prosperity as a primary goal of a state.

The evolution of these models is thus the history of state development. Post-Soviet Russia, stepping onto the path of democratic development, is gradually moving from the deeply-rooted state-centralism to partnership.

The aim of the following paper is to analyze the peculiarities of forming partnership relations in the process of cooperation between the state and a citizen as well as the dynamics of citizens' trust in state's institutions. To attain the established goal, it is necessary to present a theoretical basis for cooperation between a state and its citizens as well as to discuss the forms of citizens' trust in an adopted policy and the manifestation of institutions of authority.

\section{FOUNDATIONS FOR COOPERATION BETWEEN A CITIZEN AND A STATE}

The need for cooperation between a citizen and a state emerged with the origins of a state. The analysis is based on the theoretical assumptions of cooperation between a state and civil society, formulated in various historical periods in the works of Plato, Aristotle, Aurelius, Rousseau, Hobbes, Kant, Hegel, Marks, Popper, Schmitt, von Mises, Frank, Schumpeter, and others.

The works that particularly correspond with the abovementioned examples are by Russian researchers, published in recent years: Tsybulevskaya, who analyzes the methodological aspect of cooperation; ${ }^{1}$ Chernobel, who presents the rules of cooperation

О.И. Цыбулевская (еd.), Взаимодействие гражданского общества и государства в России: правовое измерение, Саратов 2013. 
between a state and civil society; ${ }^{2}$ Demushkina, who explains the peculiarities of the new, digital form of cooperation between the authorities and the society; ${ }^{3}$ Zaytsev, who points out to the deficit of dialogue in the field of communication and public relations and civil society in contemporary Russia. ${ }^{4}$

The conception of this article was influenced by T.H. Marshall's essay "Citizenship and social class". In this text, published in 1950, the author explains what he understands by the term cooperation: it is a relationship between individuals and a state, in which the responsibility of conferring rights on individuals should be placed on a state in a direct and transparent manner. However, in his conception citizens act rather as recipients and bearers of rights, but not as their subjects. This perspective focuses on passive-consumer citizenship, characterized by connotations of passivity. ${ }^{5}$

The article was strongly influenced by the monograph by Stein Ringen, a professor of sociology and social policy at the University of Oxford, Nation of Devils: Democratic Leadership and the Problem of Obedience, particularly the chapters "How To Make Officials Obey" and "How to Make Citizens Obey". The key thesis of Ringen's work, which shaped this article, is the conviction that the authorities provide at best (and rarely) only control over "others", who do not want to obey, but is unable to make them be willing to voluntarily cooperate with the government. ${ }^{7}$

A peculiar methodological point of approach to understanding contemporary features of cooperation between a state and a citizen, and of a civil society, is Nadia Urbinati's characteristics of representative democracy as a rule of opinion carried out through opinion, a distortion of the idea of democracy. The parameters of democracy formulated by the author include the constant struggle of representatives, having nationwide public debates on topics that are regarded by the citizens as essential for their lives and interests and thus sometimes transformed by them (when they vote) into valid decisions, arguments about democratic procedure which, according to her, equals political freedom. ${ }^{8}$

It appears to be justified to discuss the nature of contemporary cooperation between a state and citizens in the context of two mutually compatible phenomena: firstly, privatization and concentration of power in the sphere of political opinion, and secondly,

Г.Т. Чернобель, "Гражданское общество и государство: принципы взаимодействия (теоретический аспект)", Аграрное и земельное право, по. 1 (2013).

3 О.Н. Аемушина, “Электронное участие граждан: региональный уровень (на примере Волгоградской области)”, Мир экономики и управления, vol. 17, no. 4 (2017).

4 А.В. Зайцев, “Аиалогический дефицит в сфере коммуникации и связей с общественностью госуАарства и гражданского общества в современной России”, Вестник Северо-Восточного федерального университета им. М.К. Аммосова, vol. 11, no. 1 (2014).

5 T.H. Marshall, Class, Citizen and Social Development, with an introduction by S.M. Lipset, Garden City, N.Y. 1964.

6 С. Ринген, Народ дьяволов. Аемократические лидерь и проблема повиновения, Москва 2016.

7 Ibid., p. 114.

8 Н. Урбинати, Искаженнал демократия. Мнение, истина и народ, transl. by А. Крамечкин, Москва 2016, pp. 16, 34, 38-41. 
the increase in demagogic and polarized forms of consensus, which break the political stage into small-scale party groupings which are hostile to each other.' In the process of analyzing the phenomenon of cooperation, what will be highlighted are the peculiarities of cooperation between citizens and the state in the internet space, which Urbinati characterizes as disseminating information online that prompts citizens into belligerent sectarianism and creating homogeneous, self-referential niches by activists with identical views, even to a greater extent than the concentration of the media in the hands of a few people. ${ }^{10}$

Following the aforementioned assumptions, we will notice that one of the distinguishing features of the period around the turn of the millennium was the relative lowering of the state's prestige in public discourse, as evidenced by the varied transformations of its traditional institutions in response to the increasing challenges of today. Not only are the perceptions about the state changing, but also the logic of relations between a citizen and authorities. The Platonic notion of a state only as a place of common settlement, where people gather to help each other is gone; its place was taken by Aristotle's famous quote about a man as a political being. A state is more often perceived by people as a special, quite stable political unit, representing an organization of authority and administration separated from the population and claiming a sovereign right to govern (to require performance of actions) a specific territory and population, regardless of the consent of the latter; possessing the power and resources to fulfill its claims. ${ }^{11}$

Along with this, any state conducts its activities in accordance with the specific arrangement or social agreement concluded with its citizens. With regard to this relationship, S.L. Frank noted that governance is a bilateral relation: not just the ruler, but the ruler and the ruled together enter into relations of governance and actively build them. ${ }^{12}$ The "authority" in society does not exist where one person or one group actually forces others into subordination through formulated threats or by resorting to violence, but only where all citizens or most of them are aware of the legally sanctioned dominant position of the "rulers", i.e. where the attitude of subordinating to the idea of authorities is considered as a model that should be implemented in the common existence. ${ }^{13}$ Recognizing the validity of the condition of functioning of authorities formulated by S.L. Frank, we will prove that authorities can function for some time not only without the consent of the nation, but also without its support.

The establishment or reconstruction of a state can only take place at the will of the nation, which appears to be, as it is stated in practically all constitutions of modern

\footnotetext{
Ibid., p. 13.
}

10 Ibid., p. 15.

11 А.Г. Гринин, “Формации и цивилизации: социально-политические, этнические и духовные аспекты социологии истории”, Философия и общество, по. 5 (1997), p. 20.

12 С.А. Франк, Ауховнье основы общества Введение в сочиальную философию, Париж 1930, р. 139.

13 Ibid., p. 296. 
states, "the carrier of sovereignty and the only source of power". ${ }^{14}$ At the same time, the entire nation and each citizen treated separately are limited by the obligation to submit to the state authorities: to act in accordance with the law developed by state institutions. In this case, we will indicate three fundamental constants: a) the consent of the citizens (of the nation) to submit to the authorities; b) the obligation of the state apparatus, institutions of political authority to reach agreement with citizens (the nation) on solutions and actions taken; $c$ ) the presence and effectiveness of such a mechanism of agreement.

A state, implementing its functions, cooperates with citizens. Forms of this cooperation may vary: cooperation, dialogue, partnership, confrontation, indifference. In this context, cooperation is understood as the realization of people's ability to cooperate with a state to achieve general goals. It means ways to deal with common problems that take the interests of both the citizen and the state into account and are mutually satisfying solutions that achieve the necessary balance of the interests of a citizen, a state, and a society. Yet cooperation may not only be joint and several (negotiated), but also mutually opposing (antagonistic and even hostile). It should be emphasized that the cooperation between a state and citizens not only provides the possibility of civic control over the operation of state structures, but also determines the acceptable limits of state interference in the lives of individual citizens.

The qualitative features of this cooperation are strongly influenced by the tradition of political culture. Many aspects of the Russian socio-political life of previous centuries were tinged by paternalism and statism, recognizing the sacred nature of power. Cooperation between the state and man became in Russian history symbolically expressed by "шаlkers" (ходоки) (petitioners, lawyers, defenders), gunning for the truth and justice among the leaders - the tsar, Lenin, Putin.

The paternalistic tradition has not been eradicated even until now. It can be assumed that it will not disappear as long as the established cultural archetypes are strong.

A European reader will hardly understand the duality of the Russian soul, the amazing symbiosis of readiness to sacrifice life for freedom, for anarchism, for contempt and love for the state. This ambivalence was noticed already in the last century by Nikolai Berdyaev. This religious and political Russian philosopher believed that its origins lay in the underdevelopment of the individual identity of a man as well as in the presence of spontaneous collectivism. ${ }^{15}$

The essence of cooperation between citizens and the state in Russia is indirectly shaped by one of the strongest emotions - fear, present in all spheres of human activity, in social processes at the macro level. The manifestation of this social quality in political life is twofold: on the one hand, this is the genetically determined citizens' fear of the authorities, of the possible dangerous consequences of their decisions. This is a state of inhibited political thinking, which does not allow people to critically and independently grasp the meaning of this or that situation. What contributes to the

14 Art. 3, Конституция Российской Федерации, Москва 2019.

15 Н. Бердяев, Русская идея, Санкт-Петербург 2018, pp. 30-31. 
emergence of panic anxiety disorder, strong bouts of fear of possible (hypothetical or real) limiting of political and social rights and freedoms is life in an environment that has a deficit of objective information. In the modern political life of many countries, such a situation is latent or at times openly provoked by state representatives, who in this way try to maintain their dominance and influence at all costs. The high degree of anxiety in people also results from spiritual and moral imperfection of the current system of state authorities and its representatives. These fears, according to Elena Shestopal, are not only connected with economic problems, although superficially they appear to do so, but they rather result from the sense of alienation of the authorities from the society due to injustice and greed as well as lack of moral authority. ${ }^{16}$

On the other hand, the state itself, the ruling elite, almost always experiences the hidden fear of its people. As a rule, they act on the assumption that the government has enemies who not only do not want to obey, but they oppose social agreement. Such people are dangerous, and disobedience is contagious. ${ }^{17}$ It can be assumed that the fear of people experienced by the authorities is actually Russian democracy. In other words, democratic norms permeate into mutual relationships between citizens and the state precisely due to the authorities' fear of the possibility of "cruel and merciless" rebellion in Russia. On the other hand, the nation's fear of the authorities is a testimony to an un-democratic arrangement. Apart from this, the localized fear the administrative and intellectual elites feel for their fates and careers - they mostly fear the leader (their superior) - is often interpreted as general fear, referring to the entire population. ${ }^{18}$

It should be stressed that the culture of cooperation between a citizen and the state, developed during the historical development of Russia, was clearly of a statocentric nature. However, the multitude of declarations on the permanent and unshakeable unity of the citizen's and state's interests were invalidated by reality. No traditions stemming from ensuring supportive relations within the society, or reliable cooperation between different groups in the society, nor even correct forms of mutual relations between the state and a citizen have emerged. A new, post-Soviet culture of cooperation is in its embryonic stage.

The representatives of today's political leadership of Russia have termed the relations with the society as a strategic element of state policy several times. However, the road from declaration to implementation is long, as usual. Let us recall two statements of Vladimir Putin. First, on November 21, 2001 at the Citizens' Forum of Civic Organizations, the president of the RF declared that without genuine partnership relations between the state and the society, there can be no strong state or prosperous society: what is needed is a dialogue of equals. They realize that the efficiency of this dialogue depends, to a significant extent, on them - the representative government and

16 Е.Б. Шестопал, “Политическая повестка Аня российской власти и еѐ восприятие гражАанами”, Политические исследования, по. 2 (2011), рр. 22-23.

17 С. Ринген, Народ дьяволов..., р. 272.

18 И.В. Радиков, “Политический страх как фактор современной политики”, Bласть, vol. 25, no. 4 (2017), p. 45. 
the government in general. He hoped that at this moment which was offering Russia and its citizens really great opportunities, cooperation could become very productive as their state needed it. ${ }^{19}$

Sixteen years later, on November 3, 2017 at the Сообщество [Community] forum, the president noted that, typically for Russia, not much had changed in Russian practice: not everywhere were the officials ready for dialogue and cooperation. The president urged the citizens to be persistent in contacts with the officials, stating that citizens should have extensive possibilities of controlling the work of the authorities, positively influencing its quality and efficiency; through various mechanisms, including local self-government, they should try to protect their own interests. ${ }^{20}$

To confirm the importance of cooperation between a citizen and the state it should be noted that out of fourteen indicators to measure the effectiveness of actions undertaken by the head officials (the heads of the highest executive organs of the state government) of the Russian Federation, subjects, and that of the activity of executive organs of the RF subjects set in accordance with the Decree of the President of Russia from April 25, 2019, the criterion listed first is the level of trust in the government (the President of the RF and the most important officials [the heads of the highest executive organs of the state government] of the subjects of the RF). ${ }^{21}$

Cooperation is a bilateral process, needed not only by a citizen but also by the state. The foundation of this cooperation is established by the constitution of the RF. Thus, Art. 32 guarantees the citizens access to participation in political and social activities as well as performing social functions. Cooperation itself is considered as the participation of citizens in the governance of state matters, where individuals independently decide on the form and degree of their cooperation with the state, exercising their right to elect or to be elected, participating in referendums and the administration of justice; finally, they can exercise their rights in public service. Citizens' choices are informed by their conscious interest in political and social life, degree of their civic and political culture, and limits of their possibilities introduced by the political regime.

Let us note a specific feature here: the events of post-Soviet development of Russia and the power of free mass media made public the fact that many citizens, having entered into the service of the state, often consider at heart that their purpose is not to serve the state, society, and people but to accrue the best possible benefits for themselves and their families. This situation puts an even greater distance between the other

19 “Выступление на открытии Гражданского форума”, Президент Poccuи, 21 November 2001, at <http://kremlin.ru/events/president/transcripts/21408>, 19 November 2019.

20 “Выступление на пленарном заседании Форума активных граждан 'Сообщество”, Президент Poccuu, 3 November 2017, at <http://www.kremlin.ru/events/president/news/55994>, 19 November 2019.

21 “Указ Президента РФ от 25.04.2019 N 193 Об оценке эффективности деятельности высших Аолжностных Аиц (руководителей высших исполнительных органов государственной власти) субъектов Российской Федерации и деятельности органов исполнительной власти субъектов Российской Федерации", at <http://www.consultant.ru/document/cons_doc_LAW_323451/>, 19 November 2019. 
citizens and the state, makes the system of social and political representation inadequate and, what is more, questions the legitimacy of the state authorities.

Nevertheless, the constitution of the FR declares that the sate functionally exists in order to serve the people, stating that "Man, his rights and freedoms are the supreme value. The recognition, observance, and protection of the rights and freedoms of man and citizen shall be the obligation of the State.".2

\section{TRUST IN THE GOVERNMENT AS AN INDICATOR OF COOPERATION BETWEEN THE STATE AND A CITIZEN}

The question of trust attracted the attention of researchers at the end of the $19^{\text {th }}$ century when Ferdinand Tönnies discovered that in specific social conditions trust can transform from a personal psychological quality into an independent social factor, significantly influencing the society. ${ }^{23} \mathrm{~A}$ similar approach was taken by Émile Durkheim, who characterized mutual relations between trust and social solidarity. ${ }^{24}$ In the evolution of the human social side, the depersonification of trust occurs. Anthony Giddens emphasized the characteristic features of trust towards authorities, pointing out that their impersonal organs are, in practice, associated with specific persons who represent them. ${ }^{25}$ Thus loss of trust in a given governmental institution may be the result of idleness, amorality or corruption of their heads or representatives.

According to Giddens, two types of trust relations - personal or facework commitments and impersonal or faceless commitments - correspond to two types of trust personal (towards other individuals) and institutional (towards abstract systems and social institutions). ${ }^{26}$

The importance of the role trust plays in development of a society was noted by Francis Fukuyama, who analyzed trust as the commitment of individuals and groups within a society to a general system of values, considering that the success of "self-realization" of a specific society depends not on market principles or commitment to traditions, but on a single, permeating element of culture - the level of trust in the society. ${ }^{27}$

Piotr Sztompka also associates trust with the system of values. He introduces the notion of the "culture of trust" which becomes a determining factor in the process of emergence of a civic society. ${ }^{28}$ Let us note an important thought here: developed

Art. 2, Конституция Российской Федерации...

From: А.Б. Беспарточный, Аоверие в системе сочиальныц отношений населения региона, Москва 2012, p. 11.

24 Э. Аюркгейм, О разделении общественного труда, Москва 2011.

Э. ГиАленс, “Последствия модернити”, in В.А. Иноземцев (ed.), Новая постиндустриальная волна на Западе. Антология, Москва 1999.

Ibid., p. 47.

Ф. Фукуяма, Аоверие. Социальнье добродетели и путь к проиветанию, Москва 2004, р. 23.

28

П. Штомпка, Аоверие - основа общества, Москва 2012. 
political culture and positive social experience lies at the foundation of the culture of trust, while negative experience creates a culture of distrust.

Following the tradition of the interactive approach, Niklas Luhmann defines trust as a mechanism aiming at minimizing risk and a specific socio-cultural means that facilitates the realization of acting potential. ${ }^{29}$

Thus perception of political institutions and leaders is shaped, to a great extent, by the level of citizens' political culture. A specific person often becomes for the citizens a symbol of a political institution. Such a combination of the personal and the institutional can lead to an adverse effect. Charisma-based trust pays great dividends, improving the perception of the government to an extent that sometimes cannot be reached even after long years of tedious, efficient work. This effect is well known to Russian authorities and willingly utilized (e.g. the phenomenon of Boris Yeltsin or Vladimir Putin).

Political trust is dependent on two factors: firstly, the source of trust (external/exogenous and internal/endogenous factors) and secondly, the level of trust factors (macrolevel, micro-level).

The exogenous nature of political trust is based on the theory of political culture (Almond, Verba, Inglehart, Putnam, the representatives of critical trend: M.W. Foley, R. Jackman, M. Levi, and others). Within this approach political trust is presented as a continuation or projection of interpersonal trust, adopted at an early stage of life and later deciding about the assessment of politics (political institutions). This allows us to explain the low level of trust in the institutions in Russia - a state of democratic transition with the inheritance of an autocratic political culture.

Conversely, the institutional approach perceives the source of trust in people's judgments regarding the work of different government institutions (J. Coleman, P. Dasgupta, K. Orren, S. Skowronek, K. Shepsle, D. Stark, and others). Accepting the endogenous nature and rationality of trust, the adherents of this approach consider institutional trust of the civil society to be an effect, not a cause of the efficiency of political governance. Not denying the influence of political culture and socialization as external factors of trust, they interpret their function as auxiliary (complementary). Let us again emphasize: it is the efficiency of the activity of political institutions and leaders that generates trust in them, while the lack of success or positive dynamics in their actions breeds apathy, scepticism, and distrust.

Apart from the two abovementioned approaches, mechanisms of shaping group identity and self-identification, which have a decisive influence on individual perception of other people and trust towards them due to the feeling of attachment towards a particular community, are known to play a role in building trust.

In the analysis of political trust, it appears to be fundamentally important to separate the subject and the object. The object of political trust can be: a specific individual (a political leader, a civil servant or an official); a political institution or an institutional

29 Н. Ауман, Социальныце системьь. Очерк общей теории, transl. bу И.А. Газиев, Санкт-Петербург 2007, pp. 183-184. 
system; the defense and law enforcement institutions (president, prime minister, parliament, political parties, courts and prosecution institutions, police, military forces etc.); political leadership considered as undifferentiated social actor, integrating the policy they implement, both personalized and institutional features, in itself.

The subjects of political trust include: citizens, political elites, business structures, civil society institutions (the church, mass media, non-commercial organizations), defense, and law enforcement institutions.

Trust emerges based on the attributes of the trusting subject and trustworthiness of the object. The subjective perception of trustworthiness is the basis or foundation of trust considered as expectations and trust-based actions. The subject of trust determines trustworthiness either though gathering knowledge and experience or by reputation, which can represent the stockpiled trust, accrued in the past, and through the presence of guarantees (contracts, assets etc.). ${ }^{30}$

\section{THE DEGREE OF POLITICAL TRUST OF RUSSIAN CITIZENS IN THEIR LEADERS}

Each era makes new demands on political leaders. What is said to be the main determinants of political trust in a leader today are: the strength of character, political will and decisiveness, political intuition and authority, and political wisdom. Russian researchers have discovered that the citizens primarily mark caring for people (78.4\%), productivity and competence $(77.0 \%)$, and moral purity $(65.5 \%)^{31}$ on the list of personality features influencing the trust in the person of a political leader. Justice and responsive participation become the key features of a desirable political leader who people trust. Characteristics of a trusted politician included a combination of seriousness and honesty considered as a personal goal with activity, optimism, and cheerful disposition as a style of cooperation with people. The closer the politician's perceived personality was to this desired image of a people's leader, the higher the level of trust.

We can also mention features that undermine trust in a political leader: egoism, disregard for people around, pride, lack of conscientiousness, inconsistence, aggression and dishonesty of the main officials. According to the data from the Levada Center, the percentage of Russians thinking that officials lie about the state of state matters reached $52 \%$ in 2018 ; a year earlier, it was $37 \%$. Only $12 \%$ (in contrast to $20 \%$ in the previous year) believe in officials' honesty. ${ }^{32}$

In the citizens' perception, all the above features translate into a conclusion about politicians' goals and motives for striving for power, and appropriately determine

30 B. Nooteboom, Trust. Forms, Foundations, Functions, Failures and Figures, Cheltenham 2002.

31 С.Н. Пиесовских, Феномен доверия в российском обществе. Сочиологические основы и диагностика, Москва 2004.

32 “Аевада-Центр": более половины россиян уверены, что власти скрывают истинное положение дел в стране, at <https://www.newsru.com/russia/11feb2019/opros.html>. 
trust (or lack thereof) in politicians. In the broadest sense, politicians' goals may include material benefits and power over others, the possibility of self-realization, and serving people. The table below presents data about trust/distrust in the most popular politicians.

Table 1. Dynamics of the assessment of trust/distrust in politicians in Russia in \% (May 2018-May 2019)

\begin{tabular}{|c|c|c|c|c|c|c|c|c|}
\hline & \multicolumn{4}{|c|}{ Trust } \\
\hline \multirow{2}{*}{ Politician's name } & $\mathbf{2 0 . 0 5 .}$ & $\mathbf{2 3 . 0 9 .}$ & $\mathbf{2 0 . 0 1}$ & $\mathbf{1 9 . 0 5}$ & $\mathbf{2 0 . 0 5}$ & $\mathbf{2 3 . 0 9}$ & $\mathbf{2 0 . 0 1 .}$ & $\mathbf{1 9 . 0 5 .}$ \\
& $\mathbf{2 0 1 8}$ & $\mathbf{2 0 1 8}$ & $\mathbf{2 0 1 9}$ & $\mathbf{2 0 1 9}$ & $\mathbf{2 0 1 8}$ & $\mathbf{2 0 1 8}$ & $\mathbf{2 0 1 9}$ & $\mathbf{2 0 1 9}$ \\
\hline V. Putin & 47.4 & 37.2 & 32.8 & 31.7 & 2.3 & 5.8 & 7.5 & 6.6 \\
\hline S. Lavrov & 20.8 & 16.1 & 13.4 & 14.8 & 0.1 & 0.2 & 0.3 & 0.3 \\
\hline D. Medvedew & 16.6 & 11.2 & 13.1 & 13 & 17.9 & 27 & 25.7 & 23.4 \\
\hline S. Shoygu & 9.1 & 9.5 & 9.5 & 8.8 & 0.3 & 0.5 & 0.5 & 0.7 \\
\hline V. Zhirinovsky & 12.5 & 7.3 & 7.8 & 7.6 & 33.2 & 28.6 & 24.6 & 22.9 \\
\hline G. Zyuganov & 4.9 & 7.3 & 5.8 & 5.5 & 12.2 & 12.5 & 10.6 & 10 \\
\hline A. Navalny & 0.8 & 1 & 1.2 & 1.5 & 2.5 & 2.2 & 1.5 & 2.1 \\
\hline
\end{tabular}

Source: “Аоверие к политикам”, ВЦИОМ. Рейтинги и индексыь, at <https://wciom.ru/news/ratings/ doverie_politikam/>, 19 November 2019.

This data confirms what is known to all Russians - in today's Russia there is only one leader who enjoys the greatest trust in contrast to other political leaders. Still, the president's approval dropped significantly: while until 2017 it remained above $40 \%$, starting from summer 2018 it decreased to $32 \%$. A critically low level of trust was noted in the case of the prime minister of the RF, Dmitry Medvedev.

The reasons include very insignificant results of internal policies and the decrease of citizens' income, combined with an overt manifestation of increasing wealth of officials at all levels. A connection can also be made with the reform of the pension system, implemented despite the negative attitude and against the interests of the absolute majority of citizens, as well as with the increase of taxes.

For example, a declared 2018 income of the presidential plenipotentiary envoy to the Volga federal district Igor Komarov amounted to RUB 657,278,000. Within a year, his income increased sixfold! In 2017, he held the post of a general director of the state corporation Roscosmos and declared RUB 109 million. ${ }^{33}$ The income of Yury Trutnev, the deputy prime minister and presidential plenipotentiary envoy to the Far East federal district, increased by $40 \%$. In 2018, he amassed RUB 538,396,000 (in 2017 - 377.2 million). The minister of trade and industry Denis Manturov almost doubled his income: it increased to RUB 400 million

33 Сведения о доходах, об имуществе и обязательствах имущественного характера, at <https:// www.roscosmos.ru/417/>. 
from RUB 213.7 million in $2017 .{ }^{34}$ Such a sharp contrast between the drop in real incomes of the majority of Russian citizens and the fast increase of officials' wealth alienates the government from the nation even more.

\section{THE DEGREE OF TRUST OF RUSSIAN CITIZENS IN POLITICAL INSTITUTIONS}

In Russia, every week the Russian Public Opinion Research Center makes a survey of public opinion (in more than a half of the Federation's subjects), which allows the dynamics of socio-political processes to be monitored, noting any changes in the society's moods at the right time, examining the background of specific issues and predicting the development of the political situation in the country. Let us quote some data.

Table. 2. Dynamics of the assessment of approval and disapproval of activities of Russian state institutions in \% (May 2018-May 2019)

\begin{tabular}{|c|c|c|c|c|c|c|c|c|}
\hline & \multicolumn{4}{|c|}{ Approval } & \multicolumn{4}{c|}{ Disapproval } \\
\hline & $\mathbf{1 3 . 0 5}$ & $\mathbf{2 3 . 0 9}$ & $\mathbf{2 0 . 0 1}$ & $\mathbf{1 9 . 0 5}$ & $\mathbf{1 3 . 0 5}$ & $\mathbf{2 3 . 0 9}$ & $\mathbf{2 0 . 0 1}$ & $\mathbf{1 9 . 0 5}$ \\
\hline Institution & $\mathbf{2 0 1 8}$ & $\mathbf{2 0 1 8}$ & $\mathbf{2 0 1 9}$ & $\mathbf{2 0 1 9}$ & $\mathbf{2 0 1 8}$ & $\mathbf{2 0 1 8}$ & $\mathbf{2 0 1 9}$ & $\mathbf{2 0 1 9}$ \\
\hline President of Russia & 81.5 & 63.7 & 62 & 65.8 & 10.8 & 26.3 & 28.9 & 25.2 \\
\hline Prime Minister of the RF & 44.3 & 33.9 & 33.7 & 38.4 & 37 & 50.8 & 50.9 & 47 \\
\hline Government of Russia & 52 & 40.3 & 33.7 & 42.4 & 30.3 & 45.5 & 48.7 & 45.2 \\
\hline Federation Council & 47.2 & 34.6 & 33.4 & 34.2 & 33.4 & 44.7 & 48.7 & 49 \\
\hline State Duma & 50.7 & 40.1 & 38.1 & 40.1 & 18.7 & 27.4 & 32.6 & 34.2 \\
\hline
\end{tabular}

Source: “Аеятельность государственных институтов”, ВЦИОМ. Рейтинги и индексbь, at <https:// wciom.ru/news/ratings/odobrenie_deyatelnosti_gosudarstvennyx_institutov/>, 19 November 2019.

Despite all attempts made by certain Western countries to incur distrust in Russian authorities through sanctions, the trust of Russian citizens in their president remains sufficiently high. At the same time, the level of approval of the actions of executive powers generally decreased over the last decade, from 64\% in May 2007 to 56\% in September 2012 and 33.7\% in January 2019, while the level of disapproval grew from 25\% in May 2007 to 37\% in September 2012 and 48.7\% in January 2019. Let us emphasize that the data regarding trust in executive institutions is, to a significant extent, influenced by Vladimir Putin's authority.

The highest level of trust is characteristic of the Russian army. It seems that this excellent result is a manifestation of approval for genuine transformations in the army, related to Sergey Shoygu's appointment as the Minister of Defense. The Church also holds a high level of citizens' trust. Simultaneously, the most significant level of

34 Аекмаратор, Мантуров Аенис Валентинович, https://declarator.org/person/1227/. 
disapproval is voiced by the citizens with regard to the judicial system, political parties, and the opposition.

Table. 3. Dynamics of the assessment of approval and disapproval of activities of public institutions in \% (May 2018-May 2019)

\begin{tabular}{|c|c|c|c|c|c|c|c|c|}
\hline & \multicolumn{4}{|c|}{ Approval } & \multicolumn{4}{c|}{ Disapproval } \\
\hline Institution & Jul & Sep & Jan & Apr & Jul & Sep & Jan & Apr \\
\hline & $\mathbf{2 0 1 8}$ & $\mathbf{2 0 1 8}$ & $\mathbf{2 0 1 9}$ & $\mathbf{2 0 1 9}$ & $\mathbf{2 0 1 8}$ & $\mathbf{2 0 1 8}$ & $\mathbf{2 0 1 9}$ & $\mathbf{2 0 1 9}$ \\
\hline Russian army & 84.8 & 85.2 & 84.7 & 82.4 & 5.9 & 5.4 & 7.4 & 8.2 \\
\hline Russian Orthodox Church & 65.7 & 65.8 & 69.1 & 67.1 & 18 & 18.7 & 16.4 & 19.5 \\
\hline Mass media & 53.3 & 53.6 & 51.8 & 52.6 & 31.7 & 31.9 & 35.6 & 36.4 \\
\hline Law enforcement organs & 55.7 & 55.6 & 52.8 & 55.4 & 25.6 & 26.5 & 30.2 & 30.1 \\
\hline Political parties & 33.7 & 38 & 35 & 32.2 & 34.2 & 30.8 & 38.3 & 40.1 \\
\hline Civic chamber & 37.4 & 40.5 & 38.4 & 40.1 & 19 & 20 & 23.5 & 24.1 \\
\hline Judicial system & 34.4 & 35.3 & 34.3 & 36.5 & 35.6 & 38.3 & 40.8 & 41.2 \\
\hline Trade unions & 31.3 & 34.5 & 31.1 & 33.5 & 33 & 33.6 & 36.2 & 36 \\
\hline Opposition & 29 & 31.9 & 29.7 & 34.1 & 39 & 38.6 & 42 & 39.3 \\
\hline
\end{tabular}

Source: “Аеятельность государственных институтов”, ВЦИОМ. Рейтинги и индексbl, at <https:// wciom.ru/news/ratings/odobrenie_deyatelnosti_gosudarstvennyx_institutov/>, 18 November 2019.

\section{THE MOST IMPORTANT INDICATORS OF POLITICAL TRUST IN GOVERNMENT}

A specific indicator of the attitude towards the authorities in general, which is also sufficiently precise, is the citizens' attitude towards law enforcement institutions. The loss of trust in law enforcement structures reflects a low level of respect the rule of the law during investigations and corruption in these institutions. The realization that on the one hand the police are inefficient and on the other that contacts with them are inevitable is a factor that most strongly intensifies Russians' negative attitude towards the police and its employees. From the citizens' point of view, the degree of protection against crime that the police provides does not compensate for or redeem the negative costs of police activities.

Another important indicator of political trust in the government today is trust in the institution of elections - firstly in the veracity of results. One of the main complaints of the society in the last years concerns numerous violations of election rules, falsification of the results, and the absence of competition. The citizens' distrust towards the institution of elections grew due to constant changes of election regulations, administration influencing the elections, falsifiers and violators going unpunished, the negative judicial practice of court appeals regarding illegitimate results and 
election regulation offences, and the legal limitations of observers' rights, also after appeals regarding cases of illegitimate results and electoral statute violations. This reinforced the conviction in a significant part of the society that elections in Russia are a fiction and to participate in them means lack of respect for oneself and for democratic values.

At the same time, the very fact of distrusting politicians does not mean that a large part of the society is automatically and fully excluded from all forms of political participation; on the contrary, many of them participate in all kinds of elections like before, meet political leaders or even join one of the political parties and go to meetings. What is more, a significant group of citizens, whether driven by inertia, or habit or just in case (as they used to do in the times of the Communist Party of the Soviet Union) join the ruling party and pretend to be politically active. Some of them make a game of it so as to covertly incite even stronger distrust towards the state in people. For example, when talking about her "presidential ambitions" during the presidential campaign of 2018, Ksenia Sobchak called her hypothetical presidency "a joke" and "a higherlevel art project". It seems that the underlying, covert essence of similar imitations of political activity involves a wish to further erode the society's trust in the institution of elections.

The danger of an increased deficit of trust in the institution of elections is that it has caused citizens' disappointment in the political system itself, and made a significant number of citizens detach from it.

The activity of the reorganized Central Election Commission (CEC) of the RF under Ella Panfilova significantly changed the citizens' attitude both towards this body and towards the generally understood institution of elections: in 2018, 66\% citizens responded that the CEC acts in the interest of citizens: either in the interest of the entire society ( $37 \%$ compared to $25 \%$ in 2016 ) or in the interest of the majority of the population (29\% compared to $22 \%$ in 2016). The level of trust towards the head of the CEC was declared as 62\% (distrust - 14\%). As a result, more and more citizens try not only to vote but to fight themselves for the integrity of elections (Russian Public Opinion Research Center, 2018). Civil observers made a large contribution to increasing trust in elections; the Civic Chamber prepared 146,328 people for this role in the 2018 elections. $^{35}$

The third most important indicator of the attitude towards the government is the attitude towards the judicial system, which is the guarantee of the civil contract and ensures peace at the macro-social level and constitutional stability. Yet in today's Russia people express the greatest distrust towards this very system. There are numerous facts that have caused the negative attitude towards this institution: biased verdicts, incompetence of some of the members of the judges' corps, lack of openness, and long wait for court dates.

35 Г. Мисливская, «Россияне голосуют за ЦИК», Российская газета - Федеральный выпуск, no. 58(7521), at <https://rg.ru/2018/03/20/vciom-v-rossii-vyroslo-doverie-k-vyboram-i-cik.html>. 


\section{CONCLUSIONS}

1. The contemporary Russian model of cooperation between the state and a citizen is evolving from statocentric (paternalistic and etatist) to a partnership model. There are different forms of this interaction: cooperation, dialogue, partner relations, confrontation or indifference. The complexity of this evolution is conditioned by the dragging process of post-Soviet transformations. The degree of the state's cooperation is shaped by the hybrid nature of the Russian political system, which combines the elements of democratic institutions and autocratic methods of governance. In these conditions the majority of Russian citizens does not show high level of civic and political activity as they consider themselves unable to really influence the national processes as well as those that occur in their town, district, house, courtyard or work. At the same time we note a new, positive tendency of increasing the private responsibility of citizens for what is happening in the country. According to the research of the Levada Center, the number of Russians who feel responsible for what is happening in the country increased threefold in 2018 , from $9 \%$ to $28 \%$; there were also more people trying to take responsibility for what is happening in their location - 32\% compared to $14 \%$ a year earlier. Apart from that, there was a rise in the number of Russians thinking that they are able to influence what is happening in the country from 5 to $15 \%$; in their town from 9 to $16 \%{ }^{36}$

2. The distance and alienation of many citizens not only from politics but also from the society can be explained by the fact that a large part of the society lacks values that make them consciously perceive themselves as citizens, fully-fledged and involved members of the society. No wonder - the system of civic, legal, and political education is virtually absent in the country. This determines the low level of political education as well as legal and political culture in Russia. A large number of Russian citizens reduces the notion of politics to what the government representatives (or "they") do. As long as the vector of this policy does not seem to intersect with their direct interests, the predominant emotions towards politics include irritation, a feeling that it is meaningless, corrupted, aimed at enriching the power keepers and serving their interests. The alienation of the people from the government is enhanced by an artificially created, politics-hostile culture of provocation or trolling, which is widely developed on the Internet, where fora and social networks are not merely communication channels; by uploading false, biased, and extremely subjective information, they create not only uncompromising attitude towards many important socio-political questions but also a cynical attitude to political power. In this context, the statement that politics is dirty, connected with lies and violence, has taken quite deep roots in the society's consciousness.

36 ““ $\Lambda$ евада-центр”: россияне почувствовали больше ответственности за происходящее в стране”, Новая газета, 31 October 2018, at <https://www.novayagazeta.ru/news/2018/10/31/146388-levada-tsentr-rossiyane-pochuvstvovali-bolshe-otvetstvennosti-za-proishodyaschee-v-strane>, 19 November 2019. 
3. The trust people put in the government is becoming an indicator of cooperation between the state and a citizen. Under conditions of unformed democratic culture of cooperation between the state and society, the attitude of the majority of citizens towards today's political power in Russia is built on a high level of trust in Vladimir Putin, connected with his aspirations to return Russia to the status of a world power and to give the sense of being proud of their country back to Russians. This trust is becoming a great resource that can be utilized in solving specific practical issues. However, this confidence is not limitless. The loss of trust towards different government institutions can be a result of idleness, lack of morals or the corruption of particular leaders or representatives of authorities.

Thus one of the most important problems of the government becomes raising the level of trust in political institutions because where the original trust dies, where open indifference towards the government itself and to its actions appears - a conflict between the government and the society builds up. If the collected negative energy of the bottom masses clashes with the inconsiderate actions of the people at the top, it becomes a powerful disrupting factor in society.

\section{BIBLIOGRAPHY}

Marshall T.H., Class, Citizen and Social Development, with an introduction by S.M. Lipset, Garden City, N.Y. 1964.

Nooteboom B., Trust. Forms, Foundations, Functions, Failures and Figures, Cheltenham 2002, https://doi.org/10.4337/9781781950883.

Бердяев Н., Русскал идея, Санкт-Петербург 2018.

Беспарточный А.Б., Аоверие в системе социальныц отношений населения региона, Москва 2012.

“Более половины россиян обвиняют чиновников во Ажи о положении дел в стране", Аeвада-Центрр, 11 February 2019, at <https://www.levada.ru/2019/02/11/bolee-polovinyrossiyan-obvinyayut-chinovnikov-vo-lzhi-o-polozhenii-del-v-strane/ $>$.

“Выступкение на открытии ГражАанского форума”, Президент России, 21 November 2001, at $<$ http://kremlin.ru/events/president/transcripts/21408>.

“Выступление на пленарном заседании Форума активных граждан 'Сообщество”, Президент Poccuu, 3 November 2017, at <http://www.kremlin.ru/events/president/news/55994>.

Гидаенс Э., “Последствия модернити”, in В.А. Иноземцев (ed.), Новая постиндустриальная волна на Западе. Антология, Москва 1999.

“Год работы в цифрах и фактах: обзор Общественной палаты РФ", Общественнал палаma Российской Федеращии, 22 Мау 2018, at <https://www.oprf.ru/press/news/2018/ newsitem/45346>.

Гринин А.Г., “Формации и цивимизации: социально-политические, этнические и духовные аспекты социологии истории”, Философия и общество, nо. 5 (1997).

Аекмаратор, Мантуров Аенис Валентинович, at $<$ https://declarator.org/person/1227/>.

Аемушина О.Н., “Электронное участие гражАан: региональный уровень (на примере 
Волгоградской области)", Мир экономики и управления, vol. 17, no. 4 (2017), https:// doi.org/10.25205/2542-0429-2017-17-4-190-200.

“Аеятельность государственных институтов”, ВЦИОМ. Рейтинги и индексьь, at <https:// wciom.ru/news/ratings/odobrenie_deyatelnosti_gosudarstvennyx_institutov/>.

Аоверие к политикам", ВЦИОМ. Рейтинги и индексьь, at <https://wciom.ru/news/ratings/ doverie_politikam/>.

Аюркгейм Э., О разделении общественного труда, Москва 2011.

Зайцев А.В., “Аиалогический дефицит в сфере коммуникации и связей с общественностью государства и гражданского общества в современной России”, Вестник Северо-Восточного федерального университета им. М.К. Аммосова, vol. 11, no. 1 (2014).

Конституиия Российской Федерации, Москва 2019.

“ $\Lambda$ евада-Центр»: более половины россиян уверены, что власти скрывают истинное положение дел в стране, at <https://www.newsru.com/russia/11feb2019/opros.html>.

“' $\Lambda$ евада-центр’: россияне почувствовали больше ответственности за происходящее в стране”, Новал газета, 31 October 2018, at <https://www.novayagazeta.ru/news/2018/10/31/1463 88-levada-tsentr-rossiyane-pochuvstvovali-bolshe-otvetstvennosti-za-proishodyaschee-v-strane $>$.

Иуман Н., Социальньце системьь. Очерк общей теории, transl. by И.А. Газиев, Санкт-Петербург 2007.

Пиесовских С.Н., Феномен доверия в российском обществе: сочиологические основы и диагностика, Москва 2004.

“Пресс-выпуск № 3610”, ВЦИОМ. Рейтинги и индексъь, 20 March 2018, at <https://wciom. ru/index.php?id=236\&uid=116755>.

Радиков И.В., “Политический страх как фактор современной политики”, Bласть, vol. 25, no. 4 (2017).

Ринген С., Народ дьяволов: демократические лидеры и проблема повиновения, Москва 2016.

Сведения о доходах, об имуществе и обязательствах имущественного характера, аt <https://www.roscosmos.ru/417/>.

“Указ Президента РФ от 25.04.2019 N 193 Об оценке эффективности деятельности высших должностных миц (руководителей высших исполнительных органов государственной власти) субъектов Российской Федерации и деятельности органов исполнительной власти субъектов Российской Федерации", at <http://www.consultant.ru/ document/cons_doc_LAW_323451/>.

Урбинати Н., Искаженная демократия. Мнение, истина и народ, transl. by А. Кралечкин, Москва 2016.

Франк С.А., Ауховные основы общества Введение в сочиальную философию, Париж 1930.

Фукуяма Ф., Аоверие: сочиальнье добродетели и путь к процветанию, Москва 2004.

Цыбулевская О.И. (еd.), Взаимодействие гражданского общества и государства в России: правовое измерение, Саратов 2013.

Чернобель Г.Т., “ГражАанское общество и государство: принципы взаимодействия (теоретический аспект)", Аграрное и земельное право, по. 1 (2013).

Шестопац Е.Б., "Политическая повестка Аня российской власти и еѐ восприятие гражданами”, Политические исследования, по. 2 (2011).

Штомпка П., Аоверие - основа обшества, Москва 2012. 
Ivan RADIKOV - Doctor of Political Science, Professor at the Department of Russian Politics, Head of the Department of Russian Politics at the Faculty of Political Science, St. Petersburg State University. Main directions of scientific research: modern political theory, Russian politics, national security theory, philosophy and politics of force and violence. Major publications: Политика и начиональнал безопасность, St. Petersburg 2004; Политические идеологии: история и современность, St. Petersburg 2007; "Политический страх как фактор современной политики", Bласть, no. 4 (2017); "Государственность и гражданство как базовые концепты российского политического образования”, Политика и общество, по. 10 (2015); "Impact of Sanctions on the Level of Citizens' Political Confidence in the Power in Russia: the Incentive Role of the Media”, Media Watch, vol. 10, no. 3 (2019). 